\title{
Establishment of Shoreline Buffer Zone through Rehabilitation of Degraded Coastal Mangroves
}

\author{
Raja Barizan Raja Sulaiman ${ }^{1, *}$ and Farah Shahanim Mohamed Mohidin ${ }^{2}$ \\ ${ }^{1}$ Forest Research Institute of Malaysia (FRIM), 52109, Kepong, Selangor, Malaysia
}

\begin{abstract}
After the 2004 tragic tsunami that struck the western coastlines of Peninsular Malaysia and several Asian countries, which claimed thousands of lives and inflicted substantial damage to properties and economy of affected areas, the Malaysian government established a task force namely "Special National Task Force on Planting of Mangrove and Other Suitable Species in Coastal Areas". The main role of the task force was to identify coastal areas for restoration, conservation, protection and promotion of research related to planting of mangrove species. One of the Technical Committee is on Research and Development (RDTC) led by The Forest Research Institute Malaysia (FRIM) and was given the task to carry out research and development related to mangrove forest rehabilitation as well as the conservation at the areas that have high risk of coastal erosion. The seaward mangrove plot of $200 \mathrm{~m} \times 40 \mathrm{~m}$, was established at the beach of Sungai Haji Dorani, Selangor, Kuala Bernam Forest Reserved in December 2007. The objective of the study was to demonstrate that the new established seaward mangrove supports the effort in preserving the shoreline and act as natural protection zones in reducing the effects of natural disaster and soil erosion. The finding of the study has shown that after five years, the seaward mangroves successfully executed as a natural buffer and subsequently improved biodiversity of Kuala Bernam mangrove Forest Reserved at Sungai Haji Dorani.
\end{abstract}

\section{Introduction}

The coastal forests play valuable roles in foreshore protection especially in reducing coastal erosion and impacts of storm surge. It represents an important ecosystem and has been accorded high priority in maintaining protective and productive functions along the coastlines. About $35 \%$ of mangrove forest area was lost worldwide during the $1980 \mathrm{~s}$ and 1990 s alone [1] with losses of $50-80 \%$ in some regions [2]. The global loss of mangroves can be attributed largely to human population growth and development in the coastal zone. Specific reasons are urban development, aquaculture, conversion to agriculture such as rice

\footnotetext{
* Corresponding author: barizan@frim.gov.my
} 
farming, and overexploitation of timber. These losses matter, as mangroves provide numerous services and benefits to nature and to people. Mangroves play an important role in buffering coastlines against storm surges and tsunamis through wave attenuation $[3,4,5$, 6]. Studies have shown that the flooded area produced by Hurricane Wilma in 2005 in southwestern Florida would have extended $70 \%$ further inland without the protection of the 6-30 km zone of mangroves $[7,8]$ and mangroves reduced the loss of human life from the 1999 cyclone that struck Orissa, India [9]. Loss of mangroves will result in less protection from both flooding and high winds.

After the 2004 tragic tsunami that struck the north-west coast of Peninsular Malaysia and several Asian countries, which claimed thousands of lives and inflicted substantial damage to properties and economy of affected areas, the Malaysia government recognized and aware the crucial role of coastal forests. The Malaysia government is concerned about their existence and committed to manage, rehabilitate and conserve the forests. Apart from that the tsunami tragedy has made the tree planting efforts initiated in early 1980s by the Forestry Department of Peninsular Malaysia (FDPM) very much relevant and become more important to serve as costal protection and nature shield [10].

Meanwhile, the choice of appropriate mangrove species to protect coastlines is crucial. Mangrove species differed in their drag force and hydraulic resistance in relation to tsunami height. They also differ in their ability to recolonize new or degraded habitats. This observation implies the importance of preserving or selecting appropriate species that are (a) viable and robust to recolonize the zones intended for them and (b) that can act as wave barriers to offer sufficient shoreline protection. Mangrove replanting in Malaysia at high risk sites achieved limited success mainly due to soil erosion. In regards to this, Forest Research Institute of Malaysia (FRIM) has taken the responsibility in accomplishing a comprehensive research regarding this matter. A few promising results from the established research can be shared. Therefore, the objective of this paper is to conduct a study on rehabilitating and conserving the degraded coastal mangroves using innovative planting techniques with the aims to establish a seaward mangrove and act as natural protection zones in reducing the effects of natural disaster and soil erosion.

\section{National task force committee on tree planting programme along the coastlines}

The Malaysian government through the Ministry of Natural Resources and Environment, established a special 'National Task Force Committee on Tree Planting Programme Along the Coastlines' and the first meeting was conducted on 7 February 2005. Two technical committee were formed to assist the National Taskforce committee, namely, the Planning and Implementation Technical Committee (PPTC) which is headed by the Director General of FDPM and the Research and Development Technical Committee (RDTC) which is headed by the Director General of Forest Research Institute Malaysia (FRIM). These two committees work in parallel to ensure the success of the planting programmes to be undertaken.

The major tasks of the National Task Force were to identify coastal areas for restoration, conservation, protection and promotion of research related to planting of mangrove species. Under the Ninth Malaysia Plan (2006-2010), the Government of Malaysia had allocated RM40 million to implement the tree planting project and to carry out research and development activities along the coastal areas in Peninsular Malaysia, 
Sabah and Sarawak. The main responsibilities of the National Task Force committee are to coordinate, provide advice as well as to assess the implementation of the programme. The members of the committee comprise of representatives from the related Government Agencies at Federal and State levels, private sectors and Non-Government Organizations (NGOs).

\subsection{Planning and implementation technical committee (PPTC)}

The Technical Committee on Planning and Implementation (PPTC) led by The Forestry Department Peninsular Malaysia (FDPM) collaborated with other agencies and other related research institutions to enhanced it efforts in embarking on the tree planting programme along the coastal areas in the country. The tree planting programme of mangroves as well as other suitable coastal species has been extended to the Tenth Malaysia Plan (2011-2015) but with reduced allocation. The PPTC has successfully implemented the planting program with the support of research and development from the Technical Committee on Research and Development led by The Forest Research Institute Malaysia (FRIM). However, the National Tree Planting Program on Mangroves and Other Suitable Species for Coastline Protection by FDPM, Sabah and Sarawak, which have been implemented since 2005, were mostly conducted at low risk sites and sheltered coastal sites [11].

\subsection{Research and development technical committee (RDTC)}

The role of Research and Development Technical Committee (RDTC) was mainly on supporting the Technical Committee on Planning and Implementation (PPTC) in implementing the planting programme. However, the RDTC was given the task to carry out research and development related to mangrove forest rehabilitation and conservation at the areas that have high risk of coastal erosion. One of the activities under the RDTC was focused on ensuring a high rate of survival of mangrove seedlings planted in areas which are classified as highly eroded with strong wave actions through stabilizing the coastal mud-flats using innovative techniques.

Innovative mangrove replanting efforts require technical inputs from several specialists from various fields, for example engineers, hydrologists, ecologists and botanists to plan bio-technical options for initial ground stabilisation and subsequent mangrove replanting works. It usually requires the construction of a hard and a flexible breakwater that facilitates seawater flushing of the restoration area at high tide and promotes sediment accretions at low tide [12, 13]. Innovative pre-planting trials, species selection and enrichment planting are crucial for the success of the restoration efforts. Mangrove species of Rhizophora apiculata and R. mucronata were the favourite choice, due to its commercial value as poles and logs for charcoal and the muddy soil substrate is actually ecologically suitable habitat for both species. Whilst, Avicennia spp. prefers structured muddy sandy sites and the species has limited commercial value as firewood. Furthermore, the species are well colonised at the site and providing protective green shelterbelts as well as coastal bio-shields against wave surges and tsunamis. In other country such as the Philippines, Rhizophora $s p$. was also the preferred choice for mangrove restoration [14] and currently, Avicennia $s p$. is widely planted in degraded mangrove sites throughout the Philippines. 


\section{Methodology}

Extensive mud-flats along the west coast of the Peninsular Malaysia are devoid of vegetation and such areas are unstable to support natural succession of mangroves due to active erosion and accretion processes occurring within the area. Thus, to facilitate shoreline stabilization prior to planting, 'soft engineering' techniques were applied whereby partially submerged woven geo-textile tube sand-filled breakwaters were selected and constructed for the development of innovative planting techniques.

\subsection{Study site}

An innovative trial was conducted at the beach of D' Muara Marine Park Resort in Sungai Haji Dorani, Sungai Besar, Selangor, Peninsular Malaysia through stabilizing the coastal mudflats prior to innovative techniques of mangrove planting. The study site is located at $3^{0}$ $38^{\prime} \mathrm{N}, 101^{\circ} 01^{\prime} \mathrm{E}$ and it is about 154 kilometres to the north of Kuala Lumpur (Figures 1a $\& 1 \mathrm{~b}$ ). Annual rainfall, diurnal temperature and relative humidity were $\sim 130 \mathrm{~mm}, 24-32^{\circ} \mathrm{C}$, and $70-95 \%$, respectively [15]. The area at the study site was dominated by mud-flats of massive structure and composed of muddy and muddy sandy. An eroding shore is characterised by the general lowering of the near shore profile, formation of retreating scarps due to scouring of mangrove substrate, collapsing of mangrove trees as visible seen at the study site and deposition of shell fragments.

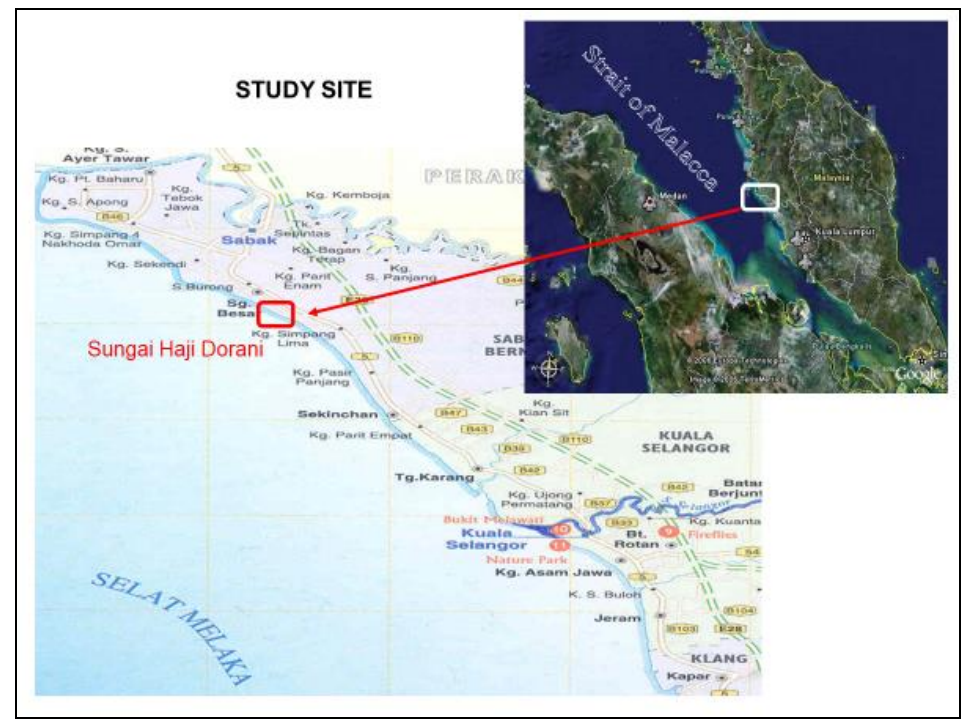

Fig. 1a. Study site location at Kuala Bernam Forest Reserved, Sungai Hj Dorani, Selangor, Penisular Malaysia 


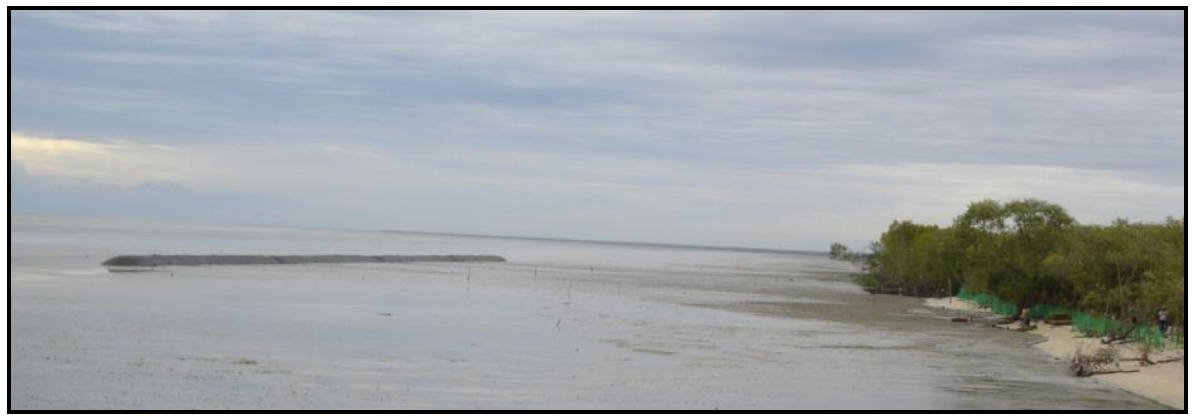

Fig. 1b. The sand-filled, wave breaker (geotubes), constructed at the beach of D' Muara Marine Park Resort, Sungai Hj Dorani, Selangor (before planting) in July 2007

\subsection{Breakwater}

The four geo-textile tubes (geotubes) sand-filled were constructed as a breakwater prior to innovative mangroves planting. Geotube is define as a large tube and fabricated from high strength woven geotextile and filled hydraulically with slurry of sand and water. The geotubes with the size of size $1.8 \mathrm{~m} \times 3.7 \mathrm{~m} \times 50 \mathrm{~m}$ per geotube were successfully constructed in July 2007 (Figure 2a). The geotubes were designed by the Malaysia's Department of Drainage and Irrigation (DID) coastal engineers. The design as well as the placement of the geotubes took into account the height of the incident waves, depth, tidal range and site conditions of the study site (Figure $2 b$ ). The maximum and minimum tidal variations recorded at Sungai $\mathrm{Hj}$ Dorani during 2008 [16] were Mean Sea Level $(\mathrm{MSL})=2.17 \mathrm{~m}$; Mean Higher High Water $(\mathrm{MHHW})=3.40 \mathrm{~m}$; Mean Lower Low Water $(\mathrm{MLLW})=0.6 \mathrm{~m}$. The maximum height of the tide was up to $2 \mathrm{~m}$ onshore everyday submerging the breakwater (geotubes). The wave height recorded at the site was $1.5-1.8 \mathrm{~m}$ at normal mean height level.

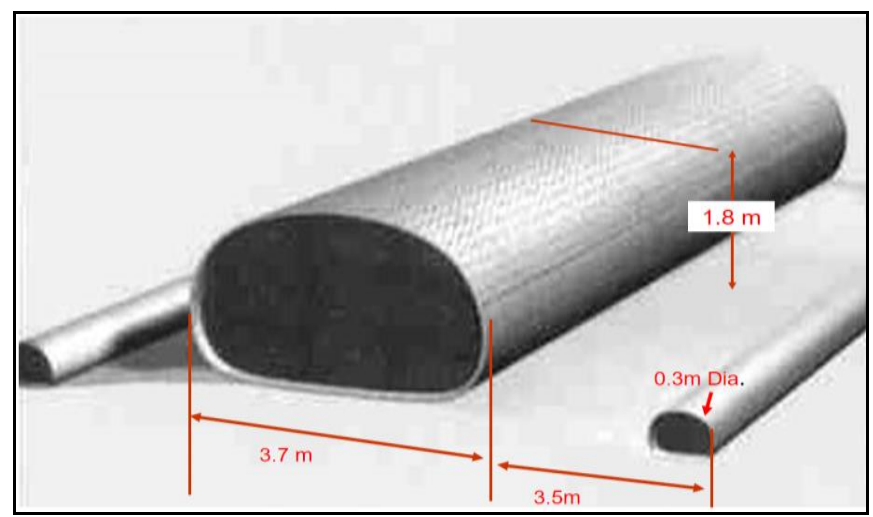

Fig. 2a. Breakwater structure (geotubes) dimension constructed at the study site 


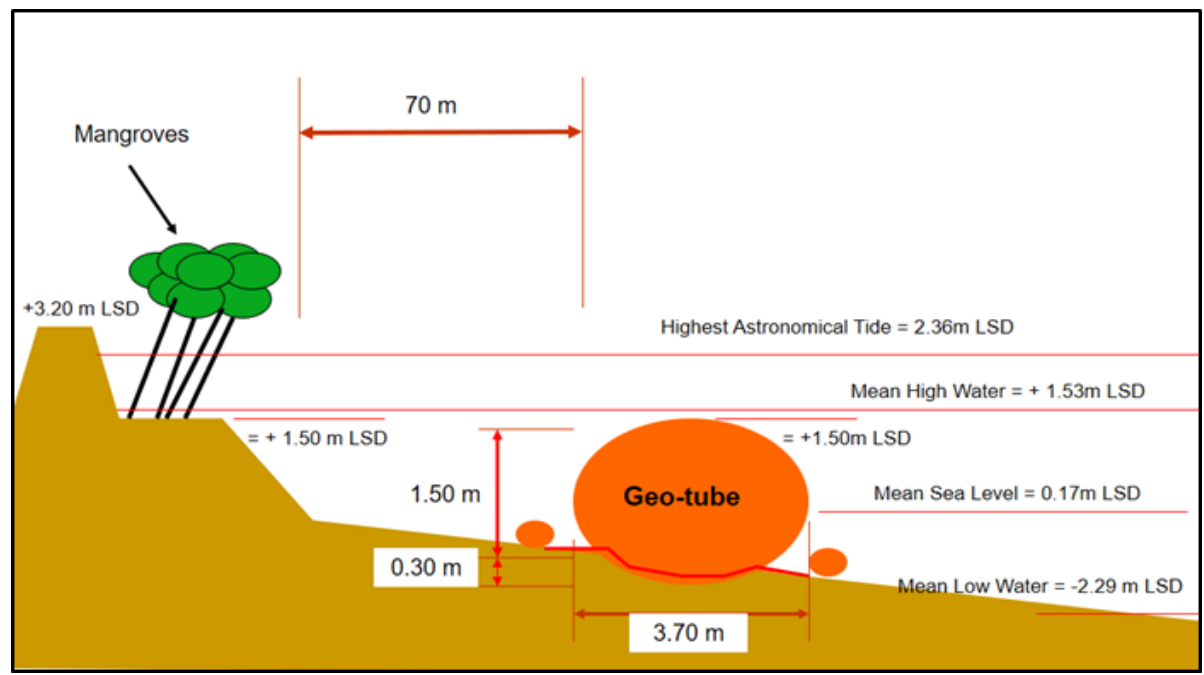

Fig. 2b. The geotubes designed by the Malaysia's Department of Drainage and Irrigation (DID) coastal engineers at the study site.

\subsection{Experimental restoration plot}

The calmer state behind the geotubes induced substrate build-up allowing the setting of semi-stable mud-flats between the geotubes and shoreline. This provides space for planting trials of mangroves using innovative planting techniques [17]. However, the mud-flat was still in semi-liquid form [18]. Thus, it provided poor anchorage for seedlings to grow and cannot withstand the strong wave and current actions. Therefore, innovative planting techniques were the alternative means for rehabilitating the site. An experimental restoration plot was established at the study site in December 2007 within the $200 \mathrm{~m} \times 40$ $\mathrm{m}$ area on mud-flats (Figure 3).

The research on suitable innovative planting techniques [19, 20,21] for mangrove planting was conducted using three innovative mangrove planting techniques, viz. i) CompMat (CM), ii) Comp-Pillow (CP) and iii) Bamboo Encasement Method (BEM). The innovative planting techniques were developed and tested, against the standard mangrove planting practice or conventional planting techniques and served as a control (CT). All planting techniques applied at the study site were monitored with the present of geotubes as breakwaters $[22,23,24,25]$. The planting spacing used for all planting techniques was $2 \mathrm{~m}$ $\times 2 \mathrm{~m}$. Three species of mangrove seedlings, viz. i) Rhizophora apiculata (bakau minyak), ii) $R$. mucronata (bakau kurap) and iii) Avicennia alba (api-api) were used to investigate the suitable planting techniques.

\subsection{Existing Kuala Bernam FR mangrove stands}

The existing fringe mangroves of Kuala Bernam has been reported in [26]. The forest consists of a total of 10 species of mangroves or mangrove associates, namely Avicennia marina, Avicennia marina var. acutissima, Avicennia alba, Bruguiera cylindrica, Aegiceras corniculatum, Xylocarpus moluccensis, Nypa fruticans, Excoecaria agallocha, Sesuvium 
portulacastrum and the fern Achrosticum aureum. Avicennia marina is the dominant species in the study area. The shoreline of Kuala Bernam FR was populated by Avicennia and Brugeira spp. and mixed species of shrubs. The soil properties of an eroding mangroves at the site was monitored [15]. It was recorded that the mortality of standing trees at the study site exposed to open sea was almost $60 \%$. Trees at the foreshore were uprooted due to the formation of retreating scarps and deposition of shell fragments on the soil surface was $0.5-3 \mathrm{~cm}$ thick and gradually washed away by the waves [27]. The major reason observed for the degradation of mangroves is the hydrological disruption. The canal behind the mangroves is blocked and the landward area has become elevated due to regular deposition of beach materials such as sand and calcareous material.

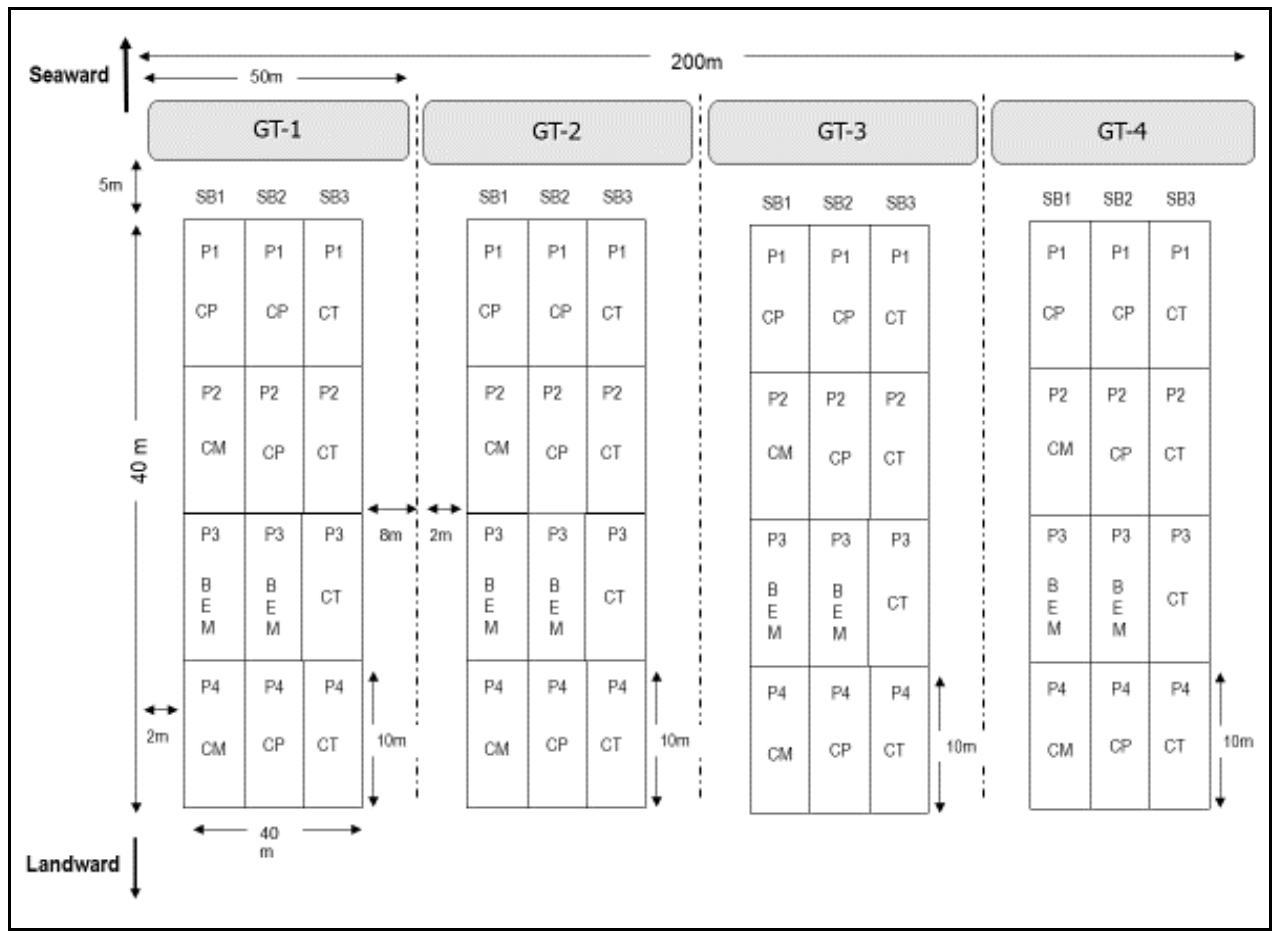

Fig. 3. An experimental restoration plot within the $200 \mathrm{~m} \times 40 \mathrm{~m}$ established at the study site. GT1, GT2, GT3, GT4 (Geotube 1, 2, 3, 4); SB1, SB2, SB3 (SubBlok 1, 2, 3); P1, P2, P3, P4 (Plot 1, 2, 3, 4); Planting techniques: CP (Comp-Pillow), CM (Comp-Mat), BEM (Bamboo Encasement Method), CT (Control).

Three blocks (Block 1, Block 2, Block 3) with the size of $200 \times 40 \mathrm{~m}$ of each block were established within the mangrove stands of Kuala Bernam FR and parallel to the experimental plot (Figure 4). The aim was to investigate as wether the newly seaward mangroves resulted from the experimental innovative rehabilitation research, effectively improved the biodiversity of the Kuala Bernam FR degraded site, after six years . However, Block 1 and Block 3 were not protected by the geotubes and seaward mangroves, whilst Block 2 was protected by the geotubes and seaward mangroves. 


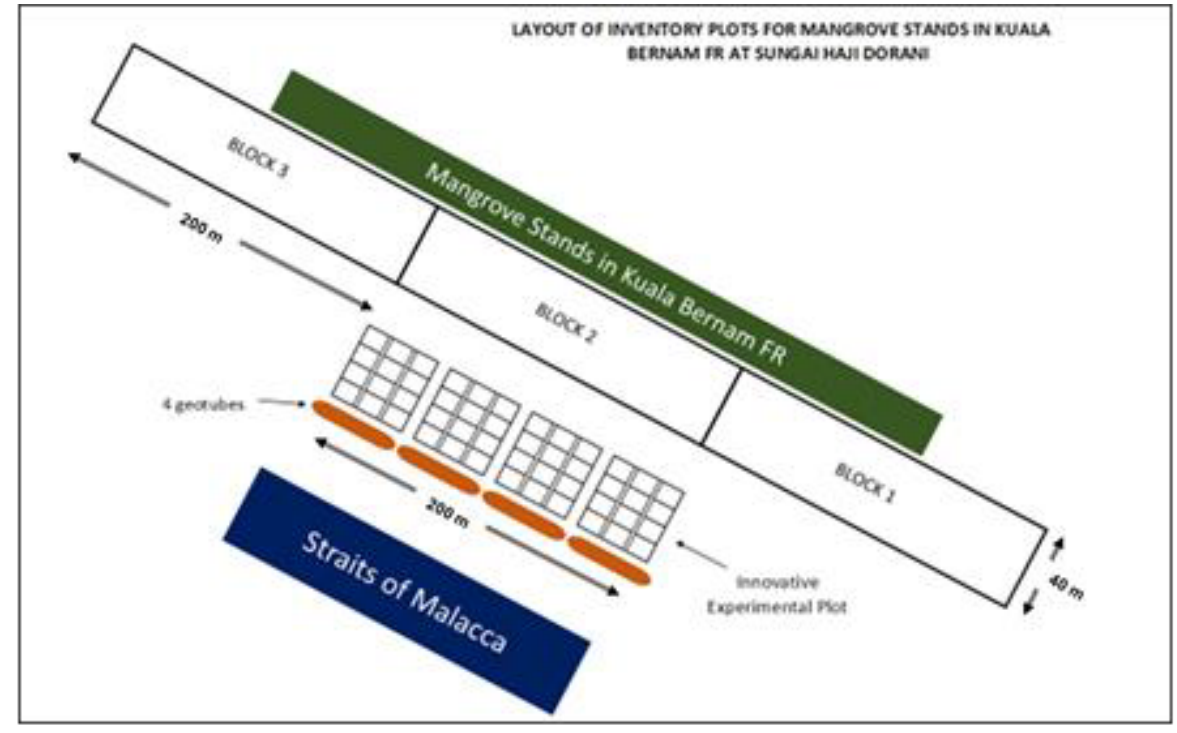

Fig. 4 Lay-out of 3 blocks natural mangrove stands of Kuala Bernam Forest Reserved near innovative experimental plot

\section{Result and discussion}

\subsection{Assessment of survival}

Assessment of survival and growth performance of the planted mangroves has shown that only two innovative mangrove planting techniques (Figures 5 and 6), Comp-Mat (CM) and Comp-Pillow (CP), were successful in rehabilitating the degraded mangroves at high-risk sites. The two innovative mangrove planting techniques, were successfully implemented using three species of mangroves, Rhizophora apiculata (bakau minyak), R. mucronata (bakau kurap) and Avicennia alba (api-api). Bakau minyak and bakau kurap planted using the CM planting techniques were observed to grow well and gave the highest survival rate with more than $90 \%$ at the structured mud-flats behind geotube $2(\mathrm{G} 2)$ and geotube $3(\mathrm{G} 3)$, 15 months after planting.

After 24 months, mangroves planted using CM planting techniques behind G2 and G3 still support and anchored the seedlings with mean survival ranged between $65 \%$ to $79 \%$ (Table 1). However, those mangroves planted using Comp-Pillow planting techniques drastically reduced the survival with the range of $19 \%$ to $24 \%$. Mangroves planted behind G1 and G4, regardless of planting techniques and mangroves species, gave the lowest survival as compared to those planted behind G2 and G3. The study also revealed that the conventional planting techniques were not able to support and anchored the mangroves as early as 15 months (Table 1). At a very high-risk site with more than $1.5 \mathrm{~m}$ wave height, it is not recommended to plant mangroves using conventional planting techniques, despite the presence of breakwater [27]. 
Table 1. The mean of survival (\%) of mangroves species planted within the experimental plot using different planting techniques at Sungai Hj Dorani, Selangor. Source: [26, 27]

\begin{tabular}{|c|c|c|c|c|c|c|c|c|c|}
\hline \multirow{4}{*}{$\begin{array}{l}\text { Planting } \\
\text { techniques }\end{array}$} & \multirow{4}{*}{ Species } & \multicolumn{8}{|c|}{$\begin{array}{l}\text { Survival (\%) of mangrove species planted at } \\
\text { different geotubes }\end{array}$} \\
\hline & & $15 \mathrm{n}$ & nths & ter $\mathrm{pl}$ & ting & $24 \mathrm{n}$ & nths & er pla & ting \\
\hline & & \multicolumn{8}{|c|}{ Number of geotubes } \\
\hline & & G1 & G2 & G3 & G4 & G1 & G2 & G3 & G4 \\
\hline Comp-Pillow & Avicennia $s p$ & 39 & 73 & 61 & 34 & 3 & 20 & 20 & 0 \\
\hline Comp-Pillow & Rhizophora mucronata & 44 & 70 & 52 & 0 & 2 & 24 & 20 & 0 \\
\hline Comp-Pillow & Rhizophora apiculata & 32 & 75 & 75 & 4 & 9 & 19 & 19 & 0 \\
\hline Comp-Mat & Rhizophora mucronata & 61 & 91 & 100 & 49 & 36 & 79 & 76 & 0 \\
\hline Comp-Mat & Rhizophora apiculata & 23 & 100 & 96 & 73 & 0 & 65 & 76 & 0 \\
\hline Control & Avicennia $s p$ & 0 & 20 & 0 & 0 & 0 & 0 & 0 & 0 \\
\hline Control & Rhizophora mucronata & 25 & 30 & 13 & 0 & 0 & 0 & 0 & 0 \\
\hline Control & Rhizophora apiculata & 45 & 25 & 0 & 0 & 0 & 0 & 0 & 0 \\
\hline
\end{tabular}

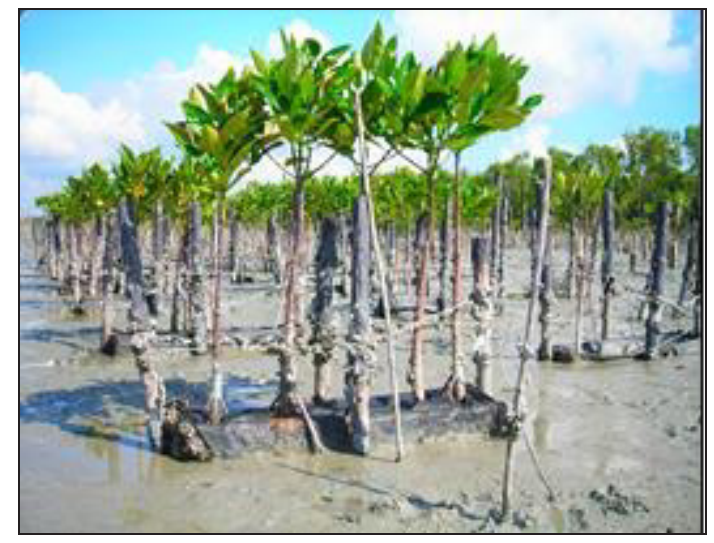

Fig. 5. Rhizophora apiculata (bakau minyak) planted using the Comp-Mat technique growing well with more than $90 \%$ survival at the structured mud-flats.

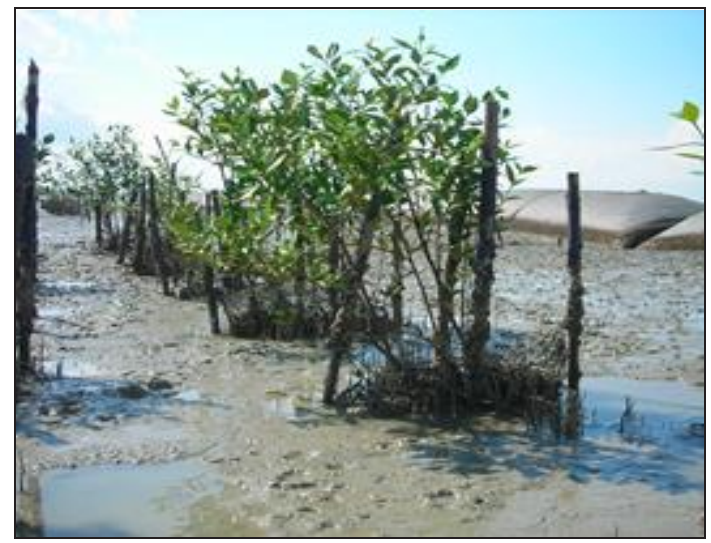

Fig. 6. Avicennia alba (api-api) planted using the Comp-Pillow technique growing well at the structured mud-flats. 


\subsection{Regeneration of mangroves}

The study has proven that two years after the construction of the geotubes, the wave breakers resulted in accreting levels of sediment. This induced substrate build-up on the landward side of the geotubes and the semi-liquid mud-flats changed to a structured mudflats. Thus, allowing a setting for the regeneration of mangroves either through replanting using innovative techniques (Figures $5 \& 6$ ) or through natural regeneration of mangrove wildings (Figure 7). Comparatively, the mass of seedlings of api-api wildings settled very well on the structured mud-flats behind geotubes G2 and G3 (Figure 7).

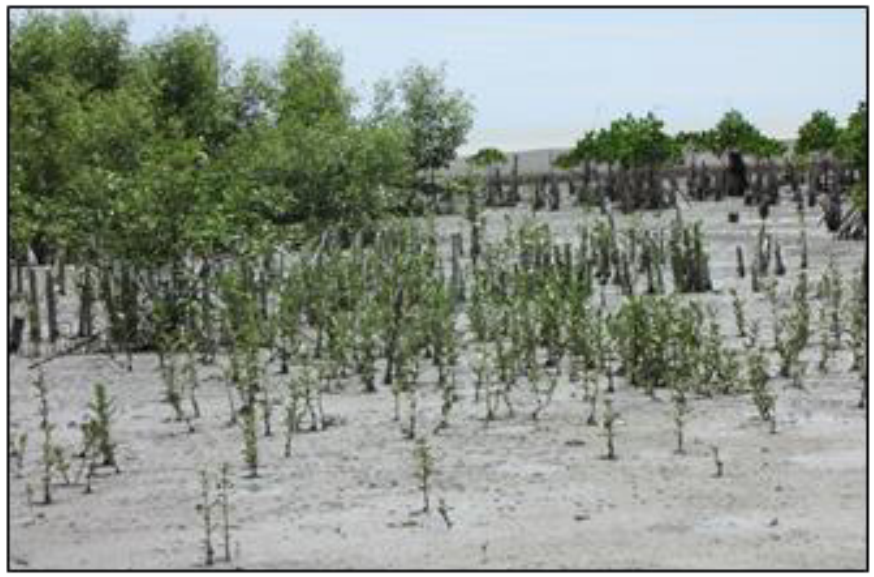

Fig. 7. Avicennia alba (api-api) wildings growing well after six months on the structured mud-flats in August year 2010.

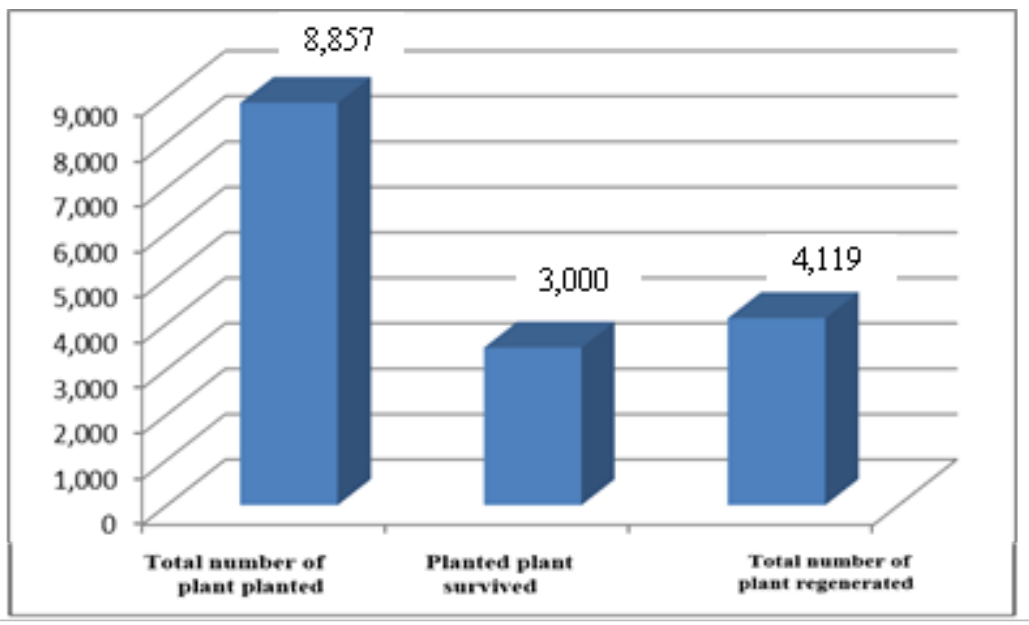

Fig. 8. Total number of mangroves found within the experimental plot after five years (2013)

Five years after the installation of geotubes, the properties of mud-flats changed from liquid to structured soil and this eventually supported the growth of planted mangroves and accelerated the natural regeneration of Avicennia species within the study plot (Figure 8). 
About $34 \%$ of planted mangroves survived, regardless of the techniques of planting (Figure 8 ). However, another $47 \%$ of mangroves naturally regenerated within the experimental plot. Those naturally regenerated plants of mangrove species were mainly Avicennia alba, $A$. oficinalis and A. marina. Source of seeds for Avicennia alba may be originated from the planted plants within the plot but the other two species of api-api, A. oficinalis and $A$. marina, the source of seeds were probably from the nearshore mangroves. The size of mangroves ranged from $10 \mathrm{~cm}$ to $5 \mathrm{~m}$ of height. These survived mangroves grew densely within the plot (Figure 9) and the trial plot has successfully demonstrated as a model on how to establish a new seaward mangrove at high risk coastal sites [27, 28].

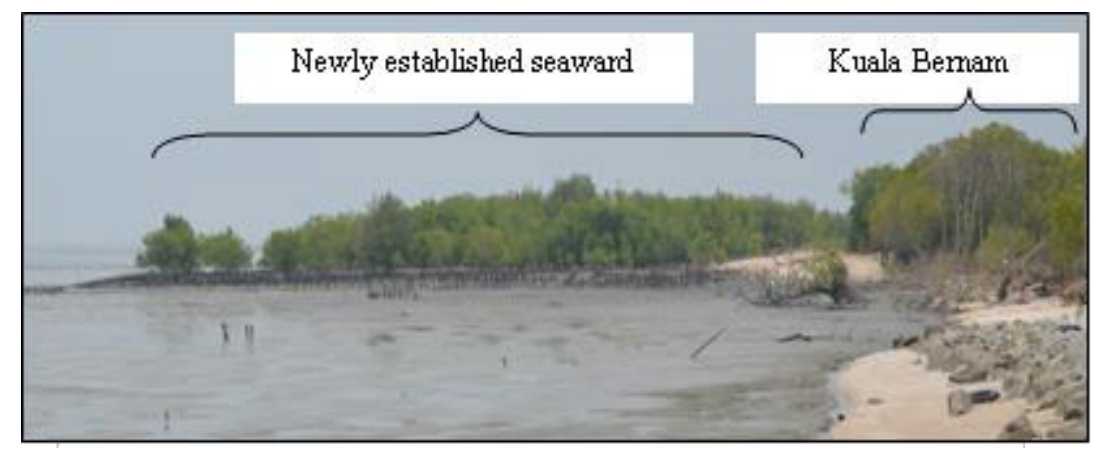

Fig. 9. New seaward mangroves established at the study site in Sungai Hj Dorani

\subsection{Biodiversity of natural stands mangrove Kuala Bernam FR}

Apparently, all three blocks showed a variation in all different types of mangroves species and non-mangroves (Table 2). Block 2, buffered by the seaward mangroves, indicated the highest abundance of mangroves and non-mangrove species with the highest individual numbers in Bruguiera cylindrica (more by $60 \%$ ) followed by A. marina (36\%) and the least was few other mangrove species (4\%) of total population. Meanwhile, Block 1 recorded high variation of mangrove and non-mangrove species. This was due to the location of block 1 closer to the resort and partly of the block was previously planted with nonmangrove species. The least numbers of mangrove species were recorded in Block 3 as the block was subjected to strong waves and erosion.

Comparatively, the total numbers of all individuals of mangroves species in all three blocks were 5,213. Therefore, variations of those species can be categorized whereby Block 1 measured $26 \%$ of total populations, Block 2 with $73 \%$ and lastly Block 3 with only $8 \%$. All three blocks illustrated that Kuala Bernam FR research plot has regenerated moderately as an impact from the mangrove rehabilitation. However, the findings also implied that Block 1 and mostly Block 3 did not restore successfully. These were probably due to the both blocks were not protected by the seaward mangroves and subjected to the strong wave actions which accelerate the rate of erosion and hindered mangroves regrowth. 
Table 2. List of species and individuals found in 3 Blocks at Kuala Bernam FR, Sungai Hj Dorani. Source: [29]

\begin{tabular}{|l|l|l|c|c|c|}
\hline \multirow{2}{*}{ NO SPECIES } & \multirow{2}{*}{ LOCAL NAME } & \multicolumn{3}{c|}{ NO. OF INDIVIDUALS } \\
\cline { 4 - 6 } & & & BLOCK 1 & BLOCK 2 & BLOCK 3 \\
\hline 1 & Avicennia alba & Api-api putih & 24 & 31 & 0 \\
\hline 2 & Avicennia marina & Api-api jambu & 444 & 1,379 & 8 \\
\hline 3 & Avicennia officinalis & Api-api ludat & 81 & 85 & 59 \\
\hline 4 & Bruguiera cylindrica & Berus & 24 & 2,214 & 339 \\
\hline 5 & Casuarina equisetifolia & Rhu & 8 & 0 & 0 \\
\hline 6 & Cocos nucifera & Kelapa & 19 & 0 & 0 \\
\hline 7 & Elaeis guineensis & Kelapa sawit & 30 & 0 & 0 \\
\hline 8 & Excoecaria agallocha & Bebuta & 85 & 59 & 15 \\
\hline 9 & Guettarda speciosa & Ketapang pasir & 0 & 4 & 0 \\
\hline 10 & Hibiscus sp & Bebaru & 55 & 11 & 9 \\
\hline 11 & Leucaena leucocephala & Petai belalang & 61 & 0 & 0 \\
\hline 12 & Morinda elliptica & Mengkudu & 26 & 0 & 0 \\
\hline 13 & Muntingia calabura & Cherry & 1 & 0 & 0 \\
\hline 14 & Musa sp & Pisang & 28 & 0 & 0 \\
\hline 15 & Psidium guajava & Jambu batu & 2 & 0 & 0 \\
\hline 16 & Rhizophora mucronata & Bakau kurap & 1 & 1 & 0 \\
\hline 17 & Scyphiphora hydrophyllacea & Chengam & 108 & 1 & 0 \\
\hline 18 & Terminalia catappa & Ketapang & 1 & 0 & 0 \\
\hline & \multicolumn{2}{|l|}{ TOTAL } & $\mathbf{9 9 8}$ & $\mathbf{3 , 7 8 5}$ & $\mathbf{4 3 0}$ \\
\hline
\end{tabular}

\section{Conclusion}

The breakwater design of the four geotubes, each measuring $1.8 \times 3.7 \times 50 \mathrm{~m}$, stretching $200 \mathrm{~m}$, and constructed at $70 \mathrm{~m}$ distance from the shoreline has proven effective in rehabilitating the mud-flats with the mix of mangrove species using innovative planting techniques. The study affirmed that the innovative planting techniques successfully rehabilitated the degraded coastal mangroves. Long term growth monitoring of the planted and regenerated mangroves within the experimental plot will determine that the newly seaward mangroves serves as an effective green belt for coastal protection. A similar project should be established in other places for comparison studies to determine the feasibility of the project in reforestation and conservation of coastal mangroves.

\section{References}

1. I. Valiela, J.L. Bowen, J.K. York. BioScience 51, 807-815 (2001).

2. E. Wolanski, S. Spagnol, S. Thomas, K. Moore, D.M. Alongi, L. Trott, A. Davidson. Estuar. Coast. Shelf Sci. 50, 85-97 (2000).

3. K. Kathiresan, N. Rajendran. Estuar. Coast. Shelf Sci. 65, 601-606 (2005).

4. E. Wolanski. In: Coastal Protection in the Aftermath of the Indian Ocean Tsunami: what Role for Forests and Trees. RAP Publication (FAO), pp.157-159 (2007). 
5. E.B. Barbier, E.W. Koch, B.R. Silliman, S.D. Hacker, E. Wolanski, J.H. Primavera, E.F. Granek, S. Polasky, S. Aswani, L.A. Cramer, D.M. Stoms. Science 319, 321323(2008).

6. S.Y. Teh, H.L. Koh, P.L.F. Liu, A.M.I. IIzani, H.L. Lee. J. Asian Earth Sci. 36 (1), 38 46 (2009).

7. K. Zhang, H. Liu, Y. Li, H. Xu, J. Shen, J. Rhome, T.J. Smith III. Estuar. Coast. Shelf Sci. 102-103, 11-23 (2012a).

8. H. Liu, K. Zhang, Y. Li, L. Xie. Cont. Shelf Res. 64, 51-65 (2013).

9. E.B. Barbier. Mar. Pollut. Bull. 109 (2), 676-681 (2016).

10. T. Dahlan, R. Suhaili, P. Noradli. Tree planting planting programme along coastal area in Peninsular Malaysia. Proceedings of the International Seminar on Wetlands \& Sustainability 2007 (2007).

11. Anonymous. Laporan Kajian Penilaian Outcome Program Penanaman Pokok Bakau Dan Spesies-Spesies Yang Sesuai Di Pesisiran Pantai Negara. ISBN 978-967-0250-202, 139pp (2014).

12. R.S. Raja Barizan, I. Shamsudin. Proceedings of the National Coastal Morphology Seminar 2010 (COSMO): The Muddy Coast of Malaysia, 17 June 2010, NAHRIM (2010).

13. N. M. Tamin, R. Zakaria, R. Hashim, Yu Yin. Estuarine, Coastal and Shelf Science 94 (2011) 334-342 (2011).

14. J.H. Primavera, J.M.A Esteban. Wetlands Ecology and Management 16 (3), 173-253 (2008).

15. V. Jeyanny, W.C. Suhaimi, K. Wan Rasidah, F. Adi, M. Azian. ISME/GLOMIS Electronic Journal 7(3), 5-6 (2009).

16. O. D. Stanley, R.R. Lewis. Journal of Coastal Development. Volume 12(3): 142 - 154 (2009).

17. H. Ismail, R.S. Raja Barizan, M. Samsudin. In: Living Land. United Nations Convention to Combact Desertification (UNCCD) ISBN 978-92-95043-24-4, Pp 178180 (2015).

18. K. Wan Rasidah, W.C. Suhaimi, M. Azian, V. Jeyanny. Proceedings of Soil Science Conference of Malaysia 2008, Ipoh, Perak. (2008).

19. R.S. Raja Barizan, M. Azian, W.S. Wan Nurzalia. Proceedings of the International Seminar on Wetlands \& Sustainability 2007, ISWS 2007, 4-6 Sept 2007, Puteri Pan Pacific Johor Bharu, Johor Malaysia (2007).

20. R.S. Raja Barizan, I. Shamsudin, H. Ismail, M.T. Siti Normasliana. Garis Panduan Teknik Inovatif Penanaman Bakau di Pesisiran Pantai Berisiko Tinggi. ISBN 978-9675221-25-5. (2009a).

21. R.S. Raja Barizan, I. Shamsudin, H. Ismail, H. Unsung Heroes of the Mud-flats. ISBN 978-967-5221-50-7, 115 pp (2010a).

22. R.S. Raja Barizan. FRIM in Focus. A quarterly of the Forest Research Institute Malaysia, March 2008. (2008).

23. R.S. Raja Barizan, I. Shamsudin, H. Mohd Nasir, M.T. Siti Normasliana. Proceedings of Soil 2008: Sustaining Soil Ecosystems with Emphasis on Coastal Soils. (2008a). 
24. I. Shamsudin, R.S. Raja Barizan, M. Azian, W.S. Wan Nurzalia. Mangrove Ecosystem Proceedings of the Meeting \& Workshop on Guidelines for the Rehabilitation of Mangroves and other Coastal Forests Damaged by Tsunamis and Other Natural Hazards in the Asia-Pacific Region. (2008b).

25. R.S. Raja Barizan, I. Shamsudin, H. Ismail, M.T. Siti Normasliana. Proceedings of the Seminar PEM 2/2009: Highlights of Non-Science Fund Projects 2009. (2009b).

26. R. Hashim, B. Kamali, N. M. Tamin, R. Zakaria. Estuarine, Coastal and Shelf Science 86: 118-124 (2010).

27. R.S. Raja Barizan, K. Wan Rashidah. Proceedings Of The International Symposium On Forest and Water. 28 November 2013, Korea Forest Research Institute (KFRI), Korea. Pp 20-28 (2013).

28. R.S. Raja Barizan, I. Shamsudin, H. Ismail, M.T. Siti Normasliana. Paper presented at the Regional Training Workshop on Mangrove Management and Restoration Techniques, ISESCO \& PERSUNGAIA, FRIM, Malaysia, 26-29 July 2010. (2010b).

29. R.S. Raja Barizan, M.M. Farah Shahanim, K. Mohamad Fahmi. Paper presented at the International Conference on Sustainable Forest Development in View of Climate Change 2016 (SFDCC-2016) 8 - 11 August 2016, Putrajaya, MALAYSIA (2016). 